\title{
Effect of Compensatory Mechanisms on Postural Disturbances and Musculoskeletal Pain in Elite Sitting Volleyball Players: Preparation of a Compensatory Intervention
}

\author{
Eliza Gaweł * (D) and Anna Zwierzchowska (iD \\ Institute of Sport Sciences, The Jerzy Kukuczka Academy of Physical Education in Katowice, \\ 40-065 Katowice, Poland; a.zwierzchowska@awf.katowice.pl \\ * Correspondence: elizagawel77@gmail.com
}

Citation: Gawel, E.; Zwierzchowska, A. Effect of Compensatory Mechanisms on Postural Disturbances and Musculoskeletal Pain in Elite Sitting Volleyball Players: Preparation of a Compensatory Intervention. Int. J. Environ. Res. Public Health 2021, 18, 10105. https:// doi.org/10.3390/ijerph181910105

Academic Editors: Hadi Nobari, Jorge Pérez-Gómez and Juan Pedro Fuentes García

Received: 24 July 2021

Accepted: 23 September 2021

Published: 26 September 2021

Publisher's Note: MDPI stays neutral with regard to jurisdictional claims in published maps and institutional affiliations.

Copyright: (c) 2021 by the authors. Licensee MDPI, Basel, Switzerland. This article is an open access article distributed under the terms and conditions of the Creative Commons Attribution (CC BY) license (https:/ / creativecommons.org/licenses/by/ $4.0 /)$.

\begin{abstract}
The aim of the study was to identify the effect of compensatory mechanisms on the prevalence of sagittal spinal curvature deformity and musculoskeletal pain and to assess the interrelationships between those components in sitting volleyball players. Twenty-one elite Polish sitting volleyball players (age $=34.1 \pm 7.5, \mathrm{BM}=77.9 \pm 16.0$ ) participated in the study in which direct participatory systematic observation and a non-invasive method were used. Both objective (anthropometric, spinal curvature-Idiag M360) and subjective (musculoskeletal ailments-NMQ = 7) measurements were performed. The Statistica 13.3 software package was used for statistical analyses. The neck, lower back (43\%), and upper back (38\%) were the most frequently reported painful areas. Of all participants, $76 \%$ reported sagittal spinal deformities. In the habitual position, the results indicated moderate correlations $(\mathrm{r}=0.5, p<0.05)$ between the lumbar concavity of the back and low back pain (LBP) and between thoracic convexity and LBP $(\mathrm{r}=0.4, p<0.05)$. Internal and external compensation have an effect on the prevalence of spinal curvature deformities in the sagittal plane, with thoracic hyperkyphosis (38\%) and lumbar hyperlordosis (33\%) being the most common. More severe lower and upper back pain were correlated with greater angles of thoracic kyphosis and lumbar lordosis in the habitual position.
\end{abstract}

Keywords: spinal curvature; Paralympic volleyball; compensation strategy; thoracic hyperkyphosis; adapted training; low back pain

\section{Introduction}

Body posture is affected by many factors. However, it is mostly determined by the shape of the spine [1], which comprises the opposing curves, i.e., kyphosis and lordosis. In a balanced spine, thoracic kyphosis and lumbar lordosis are intrinsically related, and therefore, one curvature responds to the development or disturbance of the other. Furthermore, the pelvic position strongly interacts with the spinal shape by controlling the sagittal balance between the aforementioned curvatures $[2,3]$.

Since physical activity has been acknowledged to impact spinal curvature, athlete body posture has become an area of interest for numerous scientists [1,4,5]. According to Grabara [4], sport-specific training causes multiple changes in an athlete's body build and posture, which leads to the use of adaptative strategies, even if they are not necessarily beneficial. According to Paralympic athletes, two interdependent (internal and external) mechanisms are important. Internal compensation is a necessary yet only partly beneficial compensation strategy due to a congenital or acquired impairment. However, it mostly disturbs the proper function of movement in the human body, such as trunk rotation or pelvic flattening. On the other hand, external compensatory mechanisms are developed due to the specificity of the sport practiced, which is known as the body's adaptation to the sport-specific movements. Despite the fact that the abovementioned compensatory mechanisms are essential for Paralympic athletes to keep the upright position and sagittal 
balance of the spine (internal strategy) and to meet the requirements of the sport-specific technique (external strategy), there are several disadvantages that need to be addressed. With the focus on sport-specific functional and structural movements and high training loads, athletes develop muscular dystonia and structural changes in the skeletal system; as a consequence, athletes are prone to musculoskeletal ailments [6].

As pain is known to be one of the most common problems in professional sport $[7,8]$, there is a need for studies that address the possibilities to avoid or reduce musculoskeletal pain and the negative effects of body compensation strategies, especially in Paralympic sport. These problems are especially important in sitting volleyball players since the vast majority of them have lower body impairments [9], especially amputations or limb deficiencies. These types of disabilities activate several internal compensatory mechanisms because of the changed position of the center of gravity of the body [10]. Furthermore, in sitting volleyball players, the upper limbs are constantly overloaded because of sportspecific movements, e.g., services or attacks [11], and the necessity of playing in a sitting position. Therefore, external compensatory mechanisms such as muscle imbalance are often observed in this group [11].

It should be noted that a disabled athlete cannot control his or her physiological limitations caused by a congenital or acquired disability. However, the athlete can choose to avoid or manage musculoskeletal pain and attempt to minimize the negative effects of internal and external adaptative strategies.

To the best of our knowledge, no studies in the currently available scientific literature have examined musculoskeletal pain in relation to spinal curvatures. Therefore, the aim of our study was to evaluate the effect of internal and external compensatory mechanisms on the prevalence of spinal curvature deformities in the sagittal plane and musculoskeletal pain and to assess the interrelationships between the aforementioned components. We hypothesized that lower limb disability and sitting volleyball training impact the spinal curvature in the sagittal plane. Furthermore, it was established that spinal deformities are interrelated with the prevalence of musculoskeletal pain. We assumed that the findings of our study would indicate the need for developing an adapted training program with compensatory proprioceptive exercises that could be implemented in the future as an intervention for sitting volleyball players.

\section{Materials and Methods}

\subsection{Participants}

The study examined twenty-one elite Polish sitting volleyball players $(n=6$ women; $n=15$ men) from the Polish national team. The inclusion criteria were (a) at least a minimal disability (MD) according to the World ParaVolley classification and (b) no neuromuscular or musculoskeletal disorders. Table 1 shows a description of the participants.

The amputee group used prostheses $(n=11)$ or orthopedic crutches $(n=2)$ in the activities of daily living and locomotion. Only one athlete had a bilateral amputation above the knees and used a wheelchair in everyday life. The athletes from the Les Autres group used prostheses $(n=3)$, orthopedic crutches $(n=1)$, or no supportive equipment $(n=3)$.

The measurements were carried out during a five-day national team training camp in the Jerzy Kukuczka Academy of Physical Education in Katowice, Poland. The participants were informed about the advantages and disadvantages of the study and provided written informed consent. The research protocol was approved by the Bioethics Committee for Scientific Research at the Academy of Physical Education in Katowice, Poland (No. 9/2012) and met the ethical standards of the Declaration of Helsinki, 2013. The participants were allowed to withdraw from the study at any moment. Furthermore, they were instructed to keep their normal dietary and sleeping habits for $24 \mathrm{~h}$ before the study. 
Table 1. Characterization of the sitting volleyball players.

\begin{tabular}{|c|c|}
\hline $\begin{array}{c}\text { Characteristics } \\
(n=21 ; \mathrm{nW}=6, \mathrm{nM}=15)\end{array}$ & Mean \pm SD or Percentage \\
\hline Age (years) & $34.1 \pm 7.5$ \\
\hline Body mass (kg) & $77.9 \pm 16.0$ \\
\hline Body height * $(\mathrm{cm})$ & $178.6 \pm 0.1$ \\
\hline Hip circumference $(\mathrm{cm})$ & $103.3 \pm 10.0$ \\
\hline Waist circumference $(\mathrm{cm})$ & $89.3 \pm 11.1$ \\
\hline BMI with a limb deficiency $(n=16)$ & $23.7 \pm 4.9$ \\
\hline BMI without a limb deficiency $(n=5)$ & $24.9 \pm 1.9$ \\
\hline $\mathrm{BAI}^{*}(\%)$ & $24.8 \pm 3.8$ \\
\hline Disability time (years) & $20.2 \pm 11.1$ \\
\hline Experience in sitting volleyball training (years) & $8.1 \pm 7.6$ \\
\hline \multicolumn{2}{|c|}{ Medical Classification } \\
\hline Amputees in general & $62 \%$ \\
\hline Amputees-A1 & $5 \%$ \\
\hline Amputees-A2 & $28.5 \%$ \\
\hline Amputees-A4 & $28.5 \%$ \\
\hline Les Autres in general & $38 \%$ \\
\hline Les Autres-LA5 & $33 \%$ \\
\hline Les Autres-LA6 & $5 \%$ \\
\hline
\end{tabular}

\subsection{Methods and Measurements}

A direct participatory systematic observation method was used in the study, which requires the direct participation of the studied group and the researcher, who directly assesses the participants. The Nordic Musculoskeletal Questionnaire [12] was employed to assess the prevalence and locations of musculoskeletal pain from the last seven days $(\mathrm{NMQ}=7)$ and included the following nine body parts: neck, shoulders, upper back, elbows, wrists, low back, hips/thighs, knees, and ankles/feet. Before completing the questionnaire, the athletes were instructed not to report phantom pain. Next, anthropometric measurements were taken (Figure 1). A wall-mounted stadiometer with a centimeter scale was used for body height (BH) measurements, including the wheelchair user who was able to stand on amputation stumps. Body mass (BM) was evaluated with a chair weight. Hip (HC) and waist (WC) circumferences were measured with the use of anthropometric tape on bare skin, in a lying position and according to the recommended anthropometric techniques, i.e., $\mathrm{HC}$, around the greatest convexity of the gluteal muscles below the iliac ala and WC, at the midpoint between the superior iliac crest and the lowest rib [13]. Spinal curvatures were evaluated using a non-invasive method with a Medi Mouse (Idiag M360) (Figure 1), which ensures producibility, even if two different researchers perform the measurement. The examinations were conducted in three different trunk positions, i.e., sagittal standing (arms in the habitual position), sagittal standing flexion (arms in free stance), and extension (arms crossed at the shoulders, elbows up). Before the measurements, all procedures were demonstrated and explained. The measurements started by putting the Medi Mouse at the $C_{7}$ level. Next, the device was moved with constant speed up to the $\mathrm{S}_{5}$ level. All measurements were automatically recorded on a computer with Idiag M360 software, which indicates the values from anteroposterior spinal curvatures, physiological values, the differences between them, and the type of sagittal spinal deviation (thoracic hypo/hyperkyphosis, lumbar hypo/hyperlordosis) based on individual $\mathrm{BH}, \mathrm{BM}$, gender, age, and the values from anteroposterior spinal curvatures in a habitual position. 

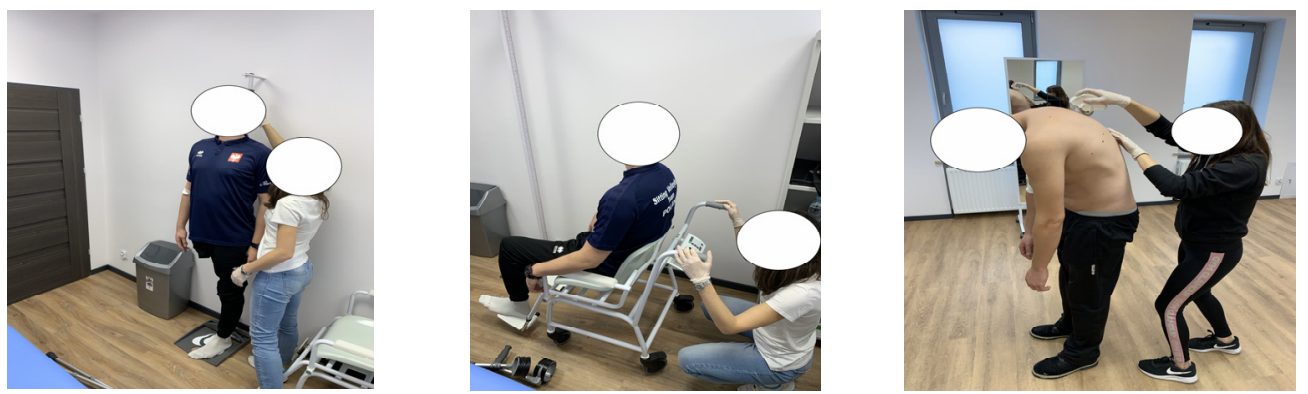

Figure 1. Examples of anthropometric measurements and spinal curvature measurements.

\subsection{Statistical Analysis}

Statistical analyses were performed with Statistica 13.3 software package (TIBCO Software Inc., Tulsa, OK, USA). Results are presented as means \pm SD for normally distributed data and as geometric means with a $95 \%$ confidence interval. The prevalence of faulty body posture in the sagittal plane and its relation to symptoms in different parts of the musculoskeletal system in the group of Paralympic athletes was compared using statistic structure index (SSI).

Pearson's correlation coefficients were computed for the characteristics of NMQ $=7$ and the parameters from Medi Mouse, recorded in different positions (sagittal standing upright, sagittal standing flexion, and extension) for the group of Paralympic athletes. The normality of thoracic kyphosis and lumbar lordosis distributions was verified with the Chi-square test. The level of statistical significance was set at $5 \%$.

\section{Results}

Table 2 presents objective results obtained from the Medi Mouse (thoracic kyphosis and lumbar lordosis angles, physiological values, and differences between actual and physiological values of the aforementioned curvatures in three positions in the sagittal plane) and subjective results of the prevalence and location of musculoskeletal pain based on the NMQ $=7$. Table 3 shows the results of statistical correlations between NMQ $=7$ and angles of anteroposterior spinal curvatures and differences between physiological norms of thoracic kyphosis and lumbar lordosis (sagittal standing, sagittal standing flexion, sagittal standing extension) based on the Medi Mouse.

The neck ( $43 \%)$, lower back ( $43 \%)$, and upper back $(38 \%)$ were the most often reported painful areas, whereas the lowest prevalence of pain was found for shoulders, elbows, and ankles/feet (19\%). Furthermore, based on the individual reports obtained from the Idiag M360 software, sagittal spinal deviations were found in the vast majority of sitting volleyball players (76\%), i.e., thoracic hyperkyphosis (38\%), lumbar hypolordosis (33\%), thoracic hypokyphosis (19\%), and lumbar hyperlordosis (14\%).

In the habitual position, the results indicate moderate correlations $(\mathrm{r}=0.5, p<0.05)$ between the deepening of lumbar lordosis and low back pain (LBP) and between deepening thoracic kyphosis and LBP $(r=0.4, p<0.05)$. Similar moderate relationships $(r=0.4, p<0.05)$ were found for the sagittal standing extension. Moreover, a correlation between neck pain and the thoracic kyphosis angle was found in both sagittal standing flexion and extension $(\mathrm{r}=0.4, p<0.05)$. Furthermore, the statistical analysis showed a moderate relationship between the prevalence of upper back pain and physiological norms of thoracic kyphosis $(\mathrm{r}=0.4, p<0.05)$. 
Table 2. Means and standard deviations (SD) of angles of anteroposterior spinal curvatures $\left(^{\circ}\right)$ in three sagittal positions and the prevalence (\%) and locations of musculoskeletal pain based on $\mathrm{NMQ}=7$.

\begin{tabular}{|c|c|c|c|}
\hline $\begin{array}{l}\text { Spinal Curvature Measurements: } \\
\text { Sagittal Plane } \\
(\mathrm{n}=21 ; \mathrm{nW}=6, \mathrm{nM}=15)\end{array}$ & Mean $\pm \operatorname{SD}\left({ }^{\circ}\right)$ & $\begin{array}{l}\text { Body Parts } \\
(\mathrm{NMQ}=7)\end{array}$ & $(n=\%)$ \\
\hline TK-sagittal standing & $37.1 \pm 18.8$ & & \\
\hline Physiological values & $38.8 \pm 18.9$ & Neck & $43 \%$ \\
\hline Difference & $1.7 \pm 2.6$ & & \\
\hline TK-sagittal standing flexion & $49.6 \pm 23.7$ & & \\
\hline Physiological values & $51.2 \pm 24.9$ & Shoulders & $19 \%$ \\
\hline Difference & $3.7 \pm 5.0$ & & \\
\hline TK-sagittal standing extension & $30.4 \pm 15.3$ & & \\
\hline Physiological values & $30.2 \pm 16.2$ & Upper back & $38 \%$ \\
\hline Difference & $2.5 \pm 3.3$ & & \\
\hline LL-sagittal standing & $18.9 \pm 13.5$ & & \\
\hline Physiological values & $20.5 \pm 14.2$ & Elbows & $19 \%$ \\
\hline Difference & $1.6 \pm 2.7$ & & \\
\hline LL-sagittal standing flexion & $21.8 \pm 13.5$ & & \\
\hline Physiological values & $20.0 \pm 12.2$ & Wrists & $24 \%$ \\
\hline Difference & $3.7 \pm 5.0$ & & \\
\hline LL-sagittal standing extension & $29.8 \pm 16.4$ & & \\
\hline \multirow{5}{*}{$\begin{array}{l}\text { Physiological values } \\
\text { Difference }\end{array}$} & $29.6 \pm 15.5$ & Lower back & $43 \%$ \\
\hline & $2.6 \pm 3.3$ & & \\
\hline & & Hips/ties & $24 \%$ \\
\hline & & Knees * & $29 \%$ \\
\hline & & Ankles/feet* & $19 \%$ \\
\hline
\end{tabular}

Table 3. The results of statistical correlations between the prevalence and location of musculoskeletal pain $(\mathrm{NMQ}=7)$ and angles of anteroposterior spinal curvatures and differences between physiological norms of thoracic kyphosis and lumbar lordosis angles (Medi Mouse).

\begin{tabular}{ccccccccccccc}
\hline $\begin{array}{c}\text { Body Parts } \\
\text { (NMQ = 7) }\end{array}$ & \multicolumn{3}{c}{ Sagittal Standing } & \multicolumn{4}{c}{ Sagittal Standing Flexion } & \multicolumn{3}{c}{ Sagittal Standing Extension } \\
\hline & TH & \pm & LL & \pm & TH & \pm & LL & \pm & TH & \pm & LL & \pm \\
\hline Neck & 0.3 & 0.3 & SI & SI & 0.4 & SI & -0.09 & SI & 0.4 & 0.2 & 0.2 & SI \\
Arms & 0.3 & SI & SI & SI & 0.3 & SI & SI & SI & SI & SI & SI & SI \\
Upper back & SI & 0.4 & 0.3 & 0.3 & 0.16 & SI & 0.15 & -0.1 & 0.15 & SI & 0.2 & SI \\
Low back & 0.4 & -0.2 & 0.5 & -0.2 & 0.2 & SI & SI & -0.1 & 0.4 & -0.2 & 0.4 & -0.2 \\
\hline
\end{tabular}

TH—thoracic kyphosis; \pm —the difference between physiological norm and TH or LL angle; SI—statistically insignificant; LL—lumbar lordosis.

\section{Discussion}

This study aimed to evaluate the effect of internal and external compensation on the prevalence of musculoskeletal pain and postural defects in elite Polish sitting volleyball players and to assess the interrelation between the aforementioned components. A major finding of this study was that the deeper the thoracic kyphosis and lumbar lordosis angles were, the higher was the prevalence of LBP reported in sagittal standing and sagittal standing extension. Furthermore, neck pain occurred more frequently in athletes with a deeper angle of thoracic kyphosis in both sagittal standing flexion and extension. Moreover, the statistical analysis showed direct proportional associations between upper back pain and physiological norms of the thoracic kyphosis angle.

The results of this study fully support our initial hypothesis and confirm that both lower limb deficiency or disability and sitting volleyball training impact the prevalence of 
spinal deviations in the sagittal plane. Furthermore, our results point out that anteroposterior spinal curvature deviations are interrelated with musculoskeletal pain, especially in the lower back ( $43 \%)$, neck ( $43 \%)$, and upper back ( $38 \%)$.

Many studies have been carried out to assess the prevalence of musculoskeletal pain in elite able-bodied volleyball players, in whom the lower back was found to be the most common location of pain [14-18]. Moreover, studies by Movahed et al. [19] showed that a greater angle of lumbar lordosis in a habitual position is associated with a higher prevalence of LBP in volleyball athletes. This result corresponds with our findings; however, LBP also contributed to a deepening of lumbar lordosis in sagittal extension and a deepening of thoracic kyphosis in both sagittal standing and extension. These findings may be related to both internal and external compensatory mechanisms that might have impacted muscle imbalance and caused spinal deviations in the sagittal plane, observed in $76 \%$ of Paralympic athletes.

It needs to be noted that sagittal balance depends on the angles of thoracic kyphosis and lumbar lordosis, whereas pelvic position strongly interacts with spinal shape by regulating the sagittal balance between the curves [2]. Moreover, the available scientific studies indicate that lower limb/limbs amputation disturbs body biomechanics [10,20]; thus, to maintain balance and upright posture, the human system must activate internal compensatory mechanisms, even if this is not fully beneficial. Unilateral limb amputation/impairment affects the spinal curvature mostly by deepening thoracic kyphosis and flattering lumbar lordosis, as reported in the vast majority of sitting volleyball players.

Furthermore, adaptation to sitting volleyball training, i.e., external compensation strategy, should also be mentioned. In the currently available scientific literature, several studies have analyzed the impact of sport-specific training on the prevalence of anteroposterior spinal curvature deviations in volleyball players $[4,21,22]$. However, it is difficult to find a study that confirms such effects in Paralympic athletes, especially amputees. Nevertheless, Grabara $[4,21]$ indicated volleyball training as a factor activating the external compensation strategy by deepening thoracic kyphosis and consequently flattening or deepening lumbar lordosis, which is consistent with the results of our study and indicates lumbar hypolordosis (33\%) and thoracic hyperkyphosis (38\%) as the most common sagittal spinal deformities in sitting volleyball players. Additionally, upper back pain appeared mostly in Paralympic athletes with incorrect values of thoracic kyphosis (38\%), which corresponds with the studies of Fett et al. [23] who found the relationships between volleyball training and the high prevalence of upper back pain.

Moreover, a specific sitting position that is taken while playing sitting volleyball should be emphasized. According to the World ParaVolley rules, players can move on the court by sliding or using their upper limbs; however, at least one part of the player's buttocks must remain on the floor while the ball is in play [24]. Because of the forced sitting position, players have a tendency to overload upper limbs and develop muscular imbalances [11] that might strongly contribute to both a deepening of thoracic kyphosis and pain in an athlete's upper body, which was found in this study.

To date, plenty of research has analyzed the prevalence of musculoskeletal pain in volleyball players, which was found mostly in the upper and lower back [25-27]. However, few studies have indicated neck pain as a significant problem in volleyball players [18,24]. Nevertheless, it is hard to find a study that demonstrates the relationships between neck pain and sagittal spinal deformities. Our results have shown a moderate correlation between neck pain and thoracic hyperkyphosis in the sagittal standing flexion and extension, which might be a consequence of the aforementioned compensation strategies.

The findings of our study may be taken into consideration by sitting volleyball players, who are characterized by the high prevalence of musculoskeletal pain and spinal curvature deformities. Therefore, we recommend, especially for Paralympic athletes, an adapted compensatory training program with proprioceptive exercises (Table A1, Appendix A), which was programmed based on the obtained subjective and objective results to prevent or reduce deformities of spinal curvature and musculoskeletal pain. 


\section{Limitations}

It should be noted that our study has several limitations that need to be acknowledged. Firstly, even though we explored the entire men's $(n=15)$ and women's $(n=6)$ Polish sitting volleyball national team, the group of participants consisted in large part of men, which leads to incomplete inference, especially regarding differences in the prevalence of spinal curvature deformities between the two genders. However, it should be noted that the female sitting volleyball national team made its debut twelve years after the male team [28], which may be associated with a smaller number of elite female athletes. Furthermore, we examined athletes only from two disability groups (amputees, Les Autres).

Secondly, the programmed compensatory exercise intervention has not yet been verified. However, it was developed according to the newest trends in kinesitherapy and corrective methodology. Simultaneously, the authors are planning its verification after extending the group of participants to those with other disabilities, e.g., spinal cord injuries. Such studies will provide important information to improve athletic performance through the prevention of musculoskeletal pain and to reduce the negative effects of internal and external compensation strategies.

\section{Conclusions}

1. Internal and external compensation have an effect on the prevalence of deformities of spinal curvature in the sagittal plane, with thoracic hyperkyphosis (38\%) and lumbar hyperlordosis (33\%) being the most common.

2. The neck, lower back ( $43 \%)$, and upper back ( $38 \%)$ were the most frequent painful areas in sitting volleyball players. More severe LBP and upper back pain were correlated with a greater angle of thoracic kyphosis and lumbar lordosis in the habitual position.

3. The findings of the study have inspired the programming of an adapted compensatory training program to decrease and prevent the abovementioned spinal deformities and musculoskeletal pain.

Author Contributions: Conceptualization, A.Z.; methodology, A.Z.; validation, A.Z.; formal analysis, E.G. and A.Z.; investigation, E.G.; writing—original draft preparation, E.G.; writing—review and editing, E.G.; supervision, A.Z. All authors have read and agreed to the published version of the manuscript.

Funding: This research was funded by The Jerzy Kukuczka Academy of Physical Education in Katowice, grant number AWF/INS/ZB2/2021.

Institutional Review Board Statement: The study was conducted according to the guidelines of the Declaration of Helsinki, and approved by the Institutional Review Board at the Academy of Physical Education in Katowice, Poland (No. 9/2012).

Informed Consent Statement: Informed consent was obtained from all subjects involved in the study.

Data Availability Statement: The data presented in the study are available on request from the corresponding author.

Acknowledgments: The authors would like to give acknowledgments to the Sitting Volleyball Polish National Team coaches Bożydar Abadżijew and Adam Malik as well as the athletes for support in doing this research. The authors also would like to thank the Student Research Group of Adapted Physical Activity, The Jerzy Kukuczka Academy of Physical Education in Katowice for help during our study.

Conflicts of Interest: The authors declare no conflict of interest. 


\section{Appendix A}

Table A1. Adapted training program with compensatory, proprioceptive exercises for sitting volleyball players.

\begin{tabular}{|c|c|c|c|c|c|c|}
\hline $\begin{array}{l}\text { Exercise } \\
\text { Number }\end{array}$ & The Kind of Exercise & $\begin{array}{l}\text { Compensatory } \\
\text { Influence }\end{array}$ & $\begin{array}{l}\text { Initial Number of } \\
\text { Series and Repetitions }\end{array}$ & $\begin{array}{c}\text { Exercise Process-Version A } \\
\text { (Easy) }\end{array}$ & $\begin{array}{c}\text { Exercise Process-Version B } \\
\text { (Difficult) }\end{array}$ & Comments \\
\hline 1. & $\begin{array}{l}\text { Mobilization \& } \\
\text { breathing exercise } \\
\text { (thoracic segment) }\end{array}$ & $\begin{array}{l}\text { - Strengthening } \\
\text { breathing muscles } \\
\text { (inspiratory/expiratory) } \\
\text { - Stretching chest } \\
\text { muscles } \\
\text { - Thoracic spine } \\
\text { mobilization }\end{array}$ & $2 \times 10$ & $\begin{array}{l}\text { I.P. } 90 / 90 \text { sit, arms behind the } \\
\text { neck, elbows inside. } \\
\text { Movement: } \\
\text { 1-4. Deep breath through the } \\
\text { nose with progressive backward } \\
\text { trunk bending and side elbow } \\
\text { abduction. } \\
\text { 5-8. Frontal trunk bending with } \\
\text { deep exhale through the mouth } \\
\text { and inside elbow adduction. } \\
\text { E.P. = I.P. }\end{array}$ & $\begin{array}{l}\text { I.P. } 90 / 90 \text { sit, arms crossed on } \\
\text { the chest } \\
\text { Movement: } \\
\text { 1-4. Deep breath through the } \\
\text { nose while going up with } \\
\text { progressive side arm abduction } \\
\text { and backward trunk bending. } \\
\text { 5-8. Frontal trunk bending with } \\
\text { a deep exhale through the } \\
\text { mouth and crossing the arms } \\
\text { across the chest while going } \\
\text { down to the initial position. } \\
\text { E.P. = I.P. }\end{array}$ & $\begin{array}{l}\text { - The inspiratory and } \\
\text { expiratory phase should } \\
\text { last } 4 \text { seconds. }\end{array}$ \\
\hline 2. & $\begin{array}{l}\text { Mobilization \& } \\
\text { breathing exercise } \\
\text { (upper limbs) }\end{array}$ & $\begin{array}{l}\text { - Enhancement of the } \\
\text { range of motion in the } \\
\text { humeral joint } \\
\text { - Stretching chest } \\
\text { muscles } \\
\text { - Strengthening } \\
\text { breathing muscles } \\
\text { (inspiratory/expiratory) }\end{array}$ & $\begin{array}{l}\text { The side without a } \\
\text { disfunction } \\
2 \times 10 \\
\text { The side with a } \\
\text { disfunction } \\
2 \times 15\end{array}$ & $\begin{array}{l}\text { I.P. Lying sideways (left side), } \\
\text { legs bent at the knee joints, arms } \\
\text { in the front, hands together. } \\
\text { Movement: } \\
\text { 1-4. Side move of the right arm } \\
\text { from the front to the right side } \\
\text { while turning the head to the } \\
\text { right and taking a deep breath } \\
\text { through the nose. } \\
\text { 5-8. Side move of the right arm } \\
\text { from the right side to the front } \\
\text { while turning the head to the } \\
\text { left and exhaling deeply } \\
\text { through the mouth. } \\
\text { E.P. = I.P. }\end{array}$ & $\begin{array}{l}\text { I.P. Lying sideways (left side), } \\
\text { legs bent at the knee joints, arms } \\
\text { in the front, hands together. } \\
\text { Movement: } \\
\text { 1-4. Side move of the right arm } \\
\text { from the front to the back with a } \\
\text { hand rotation to the dorsal } \\
\text { position while turning the head } \\
\text { to the right and taking a deep } \\
\text { breath through the nose. } \\
\text { 5-8. Side move of the right arm } \\
\text { from the back to the front with a } \\
\text { hand rotation to the areal } \\
\text { position while turning the head } \\
\text { to the left and exhaling deeply } \\
\text { through the mouth. } \\
\text { E.P. = I.P. }\end{array}$ & $\begin{array}{l}\text {-Versions A and B are } \\
\text { performed on both sides. } \\
\text { - The inspiratory and } \\
\text { expiratory phase should } \\
\text { last } 4 \text { seconds. }\end{array}$ \\
\hline
\end{tabular}


Table A1. Cont.

\begin{tabular}{|c|c|c|c|c|c|c|}
\hline $\begin{array}{l}\text { Exercise } \\
\text { Number }\end{array}$ & The Kind of Exercise & $\begin{array}{l}\text { Compensatory } \\
\text { Influence }\end{array}$ & $\begin{array}{c}\text { Initial Number of } \\
\text { Series and Repetitions }\end{array}$ & $\begin{array}{c}\text { Exercise Process-Version A } \\
\text { (Easy) }\end{array}$ & $\begin{array}{c}\text { Exercise Process-Version B } \\
\text { (Difficult) }\end{array}$ & Comments \\
\hline 3. & $\begin{array}{l}\text { Mobilization exercise } \\
\text { (lower limbs) }\end{array}$ & $\begin{array}{l}\text { - Enhancement of the } \\
\text { range of motion in the } \\
\text { hip joints } \\
\text { - Stretching the } \\
\text { iliolumbar and } \\
\text { quadriceps muscles }\end{array}$ & $\begin{array}{l}\text { The side without a } \\
\text { disfunction } \\
2 \times 10 \\
\text { The side with a } \\
\text { disfunction } \\
2 \times 15\end{array}$ & $\begin{array}{l}\text { I.P. Seated frontal bend, arms on } \\
\text { the floor. } \\
\text { Movement: } \\
\text { 1. Right leg abduction to the } \\
\text { floor. } \\
\text { 2. Right leg adduction to the } \\
\text { initial position. } \\
\text { 3. Left leg abduction to the floor. } \\
\text { 4. Left leg adduction to the } \\
\text { initial position. } \\
\text { E.P. = I.P. }\end{array}$ & $\begin{array}{l}\text { I.P. Seated frontal bend, arms to } \\
\text { the side. } \\
\text { Movement: } \\
\text { 1. Right and left leg abduction to } \\
\text { the floor (movement to the } \\
\text { right). } \\
\text { 2. Leg adduction to the initial } \\
\text { position. } \\
\text { 3. Left and right leg abduction } \\
\text { to the floor. (movement to the } \\
\text { left) } \\
\text { 4. Leg adduction to the initial } \\
\text { position. } \\
\text { E.P. = I.P. }\end{array}$ & \\
\hline 4. & $\begin{array}{l}\text { Activation exercise } \\
\text { (upper limbs) }\end{array}$ & $\begin{array}{l}\text { - Rotator cuff activation } \\
\text { - Balance the shoulder } \\
\text { blade rhythm } \\
\text { - Thoracic spine } \\
\text { activation }\end{array}$ & $\begin{array}{l}\text { Version A } \\
3 \times 10 \\
\text { Version B } \\
2 \times 8\end{array}$ & $\begin{array}{l}\text { I.P. Lying on the front, arms } \\
\text { overhead, hands vertical, } \\
\text { forehead on the floor. } \\
\text { Movement: } \\
\text { 1. Raising the arms upwards. } \\
\text { 2. Lowering the arms } \\
\text { downwards while bending the } \\
\text { elbow joints and rotating the } \\
\text { hands to the dorsal position. } \\
\text { 3. Raising the arms upwards } \\
\text { while extending the elbow joints } \\
\text { and rotating the hands to the } \\
\text { initial position. } \\
\text { 4. Lowering arms downwards. } \\
\text { E.P. = I.P. }\end{array}$ & $\begin{array}{l}\text { I.P. Lying on the side, arms } \\
\text { overhead, hands vertical, } \\
\text { forehead on the floor. } \\
\text { Movement: } \\
\text { 1. Raising the arms upwards. } \\
\text { 2. Adduction of the arms } \\
\text { sideways. } \\
\text { 3. Internal hand rotation to the } \\
\text { dorsal position } \\
\text { 4. Bending arms at the elbow } \\
\text { joints with a side move to the } \\
\text { thoracic spine. } \\
\text { 5. Lowering the elbows } \\
\text { downwards. } \\
\text { 6. Raising the elbows upwards } \\
\text { with an arm extension to the } \\
\text { side (hands in internal rotation). } \\
\text { 7. Lifting the arms upwards } \\
\text { from the front while rotating the } \\
\text { hands to the initial position } \\
\text { 8. Lowering arms downwards. } \\
\text { E.P. = I.P. }\end{array}$ & $\begin{array}{l}\text { - Before each } \\
\text { repetition-retraction and } \\
\text { depression of the } \\
\text { scapula. }\end{array}$ \\
\hline
\end{tabular}


Table A1. Cont.

\begin{tabular}{|c|c|c|c|c|c|c|}
\hline $\begin{array}{l}\text { Exercise } \\
\text { Number }\end{array}$ & The Kind of Exercise & $\begin{array}{l}\text { Compensatory } \\
\text { Influence }\end{array}$ & $\begin{array}{c}\text { Initial Number of } \\
\text { Series and Repetitions }\end{array}$ & $\begin{array}{c}\text { Exercise Process-Version A } \\
\text { (Easy) }\end{array}$ & $\begin{array}{c}\text { Exercise Process-Version B } \\
\text { (Difficult) }\end{array}$ & Comments \\
\hline 5. & $\begin{array}{l}\text { Activation exercise } \\
\text { (lower limbs) }\end{array}$ & $\begin{array}{l}\text { - Gluteus muscle } \\
\text { activation } \\
\text { - Central stability }\end{array}$ & $\begin{array}{l}\text { The side without a } \\
\text { disfunction } \\
3 \times 6 \\
\text { The side with } \\
\text { a disfunction } \\
3 \times 10\end{array}$ & $\begin{array}{l}\text { I.P. } 90 / 90 \text { sit, front foot in the } \\
\text { dorsal position, arms between } \\
\text { the knee joint. } \\
\text { Movement: } \\
\text { 1. Raising the front leg (bent at } \\
\text { the knee joint) upwards. } \\
\text { 2. Lowering the front leg to the } \\
\text { initial position. } \\
\text { E.P. = I.P. }\end{array}$ & $\begin{array}{l}\text { I.P. Four-point kneeling } \\
\text { Movement: } \\
\text { 1. Moving the left leg backward. } \\
\text { 2. Holding. } \\
\text { 3. Moving the left leg sideways. } \\
\text { 4. Lowering the left leg } \\
\text { downward. } \\
\text { 5. Moving the left leg sideways. } \\
\text { 6. Moving the left leg backward. } \\
\text { 7. Holding. } \\
\text { 8. Lowering the left leg to the } \\
\text { initial position. } \\
\text { E.P. = I.P. }\end{array}$ & $\begin{array}{l}\text { - Before each } \\
\text { repetition-scapula } \\
\text { protraction. } \\
\text { - Versions A and B are } \\
\text { performed on both sides. } \\
\text {-Version B-lumbar spine } \\
\text { and pelvis without } \\
\text { extreme rotation. }\end{array}$ \\
\hline 6. & $\begin{array}{l}\text { Activation exercise } \\
\text { (trunk) }\end{array}$ & $\begin{array}{l}\text { - Abdominal muscles } \\
\text { activation }\end{array}$ & $\begin{array}{l}\text { Version A } \\
2 \times 8 \\
\text { Version B } \\
\text { The side without a } \\
\text { disfunction } \\
2 \times 8 \\
\text { The side with a } \\
\text { disfunction } \\
2 \times 12\end{array}$ & $\begin{array}{l}\text { I.P. Lying on the front, arms } \\
\text { crossed on the chest. } \\
\text { Movement: } \\
\text { 1. Raising the trunk upwards. } \\
\text { 2-3. Holding. } \\
\text { 4. Lowering the trunk } \\
\text { downwards. } \\
\text { 5. Raising and turning the trunk } \\
\text { to the left side. } \\
\text { 6. Lowering the trunk to the } \\
\text { initial position. } \\
\text { 7. Raising and turning the trunk } \\
\text { to the right side. } \\
\text { 8. Lowering the trunk to the } \\
\text { initial position. } \\
\text { E.P. = I.P. }\end{array}$ & $\begin{array}{l}\text { I.P. Lying on the back with the } \\
\text { legs bent at the knee joints (feet } \\
\text { in a dorsal position), left arm } \\
\text { upwards, right arm on the left } \\
\text { knee joint- pushing slightly. } \\
\text { Movement: } \\
\text { 1. Lowering the left arm and the } \\
\text { right leg downwards (to the } \\
\text { straight body level). } \\
\text { 2. Raising the left arm and the } \\
\text { right leg upwards to the initial } \\
\text { position. } \\
\text { E.P. = I.P. }\end{array}$ & $\begin{array}{l}\text { - Verison A: raising and } \\
\text { lowering the trunk, } \\
\text { vertebra by vertebra. } \\
\text { - Version B: the exercise } \\
\text { is performed on both } \\
\text { sides, and the lumbar } \\
\text { spine should globally } \\
\text { touch the floor during } \\
\text { the entire motor activity. }\end{array}$ \\
\hline
\end{tabular}


Table A1. Cont.

\begin{tabular}{|c|c|c|c|c|c|c|}
\hline $\begin{array}{l}\text { Exercise } \\
\text { Number }\end{array}$ & The Kind of Exercise & $\begin{array}{l}\text { Compensatory } \\
\text { Influence }\end{array}$ & $\begin{array}{c}\text { Initial Number of } \\
\text { Series and Repetitions }\end{array}$ & $\begin{array}{c}\text { Exercise Process-Version A } \\
\text { (Easy) }\end{array}$ & $\begin{array}{c}\text { Exercise Process-Version B } \\
\text { (Difficult) }\end{array}$ & Comments \\
\hline 7. & $\begin{array}{l}\text { Directional exercise } \\
\text { (thoracic segment) }\end{array}$ & $\begin{array}{l}\text { - Stretching chest } \\
\text { muscles } \\
\text { - Strengthening the } \\
\text { latissimus dorsi muscle } \\
\text { and teres major muscle } \\
\text { - Strengthening the } \\
\text { rotator cuff } \\
\text { - Balance the shoulder } \\
\text { blade rhythm }\end{array}$ & $3 \times 10$ & $\begin{array}{l}\text { I.P. Kneeling sit, arms } \\
\text { downwards, hands are holding } \\
\text { a resistance band (hips } \\
\text { widthways). } \\
\text { Movement: } \\
\text { 1. Moving the right arm from } \\
\text { the front to the back. } \\
\text { 2. Moving the right arm from } \\
\text { the back to the front. } \\
\text { E.P. = I.P. }\end{array}$ & $\begin{array}{l}\text { I.P. Kneeling sit, arms } \\
\text { downwards, hands are holding } \\
\text { a resistance band (hips } \\
\text { widthways). } \\
\text { Movement: } \\
\text { 1. Moving the arms from the } \\
\text { front to the back. } \\
\text { 2. Moving the arms from the } \\
\text { back to the front. } \\
\text { E.P. = I.P. }\end{array}$ & $\begin{array}{l}\text { - Before each } \\
\text { repetition-retraction and } \\
\text { depression of the } \\
\text { scapula. } \\
\text { - During the exercise, } \\
\text { there should not be any } \\
\text { compensation with trunk } \\
\text { arcuation in the lumbar } \\
\text { spine } \\
\text { - Version A: the exercise } \\
\text { is performed on both } \\
\text { sides. During the entire } \\
\text { movement activity, the } \\
\text { band should be } \\
\text { maintained in a slight } \\
\text { tension. } \\
\text { - Version B: during the } \\
\text { entire movement activity, } \\
\text { the band should be } \\
\text { maintained with the } \\
\text { same tension. }\end{array}$ \\
\hline 8. & $\begin{array}{l}\text { Directional exercise } \\
\text { (thoracic segment) }\end{array}$ & $\begin{array}{l}\text { - Stretching chest } \\
\text { muscles } \\
\text { - Strengthening the } \\
\text { quadratus lumborum } \\
\text { muscle, rhomboid } \\
\text { muscle, and latissimus } \\
\text { dorsi muscle } \\
\text { - Strengthening the } \\
\text { rotator cuff } \\
\text { - Balance the } \\
\text { shoulder-blade rhythm }\end{array}$ & $3 \times 10$ & $\begin{array}{l}\text { I.P. } 90 / 90 \text { sit, arms in the front } \\
\text { (head level), hands are holding } \\
\text { the resistance band (shoulders } \\
\text { widthways). } \\
\text { Movement: } \\
\text { 1. Pulling the band from the } \\
\text { front to the side. } \\
\text { 2. Returning to the initial } \\
\text { position. } \\
\text { E.P. = I.P. }\end{array}$ & $\begin{array}{l}\text { I.P. } 90 / 90 \text { sit, arms upwards, } \\
\text { hands are holding the resistance } \\
\text { band (shoulders widthways). } \\
\text { Movement: } \\
\text { 1. Pulling the band downwards. } \\
\text { 2. Returning to the initial } \\
\text { position. } \\
\text { E.P. = I.P. }\end{array}$ & $\begin{array}{l}\text { - Before each } \\
\text { repetition-scapulas } \\
\text { retraction and } \\
\text { depression. } \\
\text { - During the entire } \\
\text { movement activity, the } \\
\text { band should be kept } \\
\text { with a slight tension. }\end{array}$ \\
\hline
\end{tabular}


Table A1. Cont.

\begin{tabular}{|c|c|c|c|c|c|c|}
\hline $\begin{array}{l}\text { Exercise } \\
\text { Number }\end{array}$ & The Kind of Exercise & $\begin{array}{l}\text { Compensatory } \\
\text { Influence }\end{array}$ & $\begin{array}{c}\text { Initial Number of } \\
\text { Series and Repetitions }\end{array}$ & $\begin{array}{c}\text { Exercise Process-Version A } \\
\text { (Easy) }\end{array}$ & $\begin{array}{c}\text { Exercise Process-Version B } \\
\text { (Difficult) }\end{array}$ & Comments \\
\hline 9. & $\begin{array}{l}\text { Directional exercise } \\
\text { (lumbar segment) }\end{array}$ & $\begin{array}{l}\text { - Strengthening gluteus } \\
\text { muscles } \\
\text { - Strengthening serratus } \\
\text { anterior muscle, superior } \\
\text { and external oblique } \\
\text { muscles } \\
\text { - Central stability }\end{array}$ & $\begin{array}{l}\text { The side without a } \\
\text { disfunction } \\
3 \times 10 \\
\text { The side with a } \\
\text { disfunction } \\
3 \times 15\end{array}$ & $\begin{array}{l}\text { I.P. Lying sideways (left side) } \\
\text { with bent legs, the left arm bent } \\
\text { at the elbow joint and lying on } \\
\text { the forearm, the right arm bent } \\
\text { at the elbow joint (on the trunk } \\
\text { level), } \\
\text { Movement: } \\
\text { 1. Raising trunk upwards while } \\
\text { raising the right leg upwards. } \\
\text { 2. Holding the trunk with a } \\
\text { right arm abduction and while } \\
\text { turning the trunk to the right. } \\
\text { 3. Holding the trunk with a } \\
\text { right arm adduction and a trunk } \\
\text { flexion to the body level. } \\
\text { 4. Lowering the trunk and legs } \\
\text { to the initial position. } \\
\text { E.P. = I.P. }\end{array}$ & $\begin{array}{l}\text { I.P. Lying sideways (left side) } \\
\text { with bent legs, the left arm bent } \\
\text { at the elbow joint and lying on } \\
\text { the forearm, the right arm } \\
\text { upwards. } \\
\text { Movement: } \\
\text { 1. Raising the trunk and right } \\
\text { leg upwards. } \\
\text { 2. Holding the trunk while } \\
\text { lowering the right leg. } \\
\text { 3. Holding the trunk while } \\
\text { raising the right leg upwards. } \\
\text { 4. Lowering the trunk and legs } \\
\text { to the initial position. } \\
\text { E.P. = I.P. }\end{array}$ & $\begin{array}{l}\text { - Before each } \\
\text { repetition-retraction and } \\
\text { depression of the } \\
\text { scapula. } \\
\text { - During the motor } \\
\text { activity, the trunk should } \\
\text { be stabilized. }\end{array}$ \\
\hline 10. & $\begin{array}{l}\text { Directional exercise } \\
\text { (lumbar segment) }\end{array}$ & $\begin{array}{l}\text { - Strengthening the } \\
\text { rectus abdominis muscle } \\
\text { (version A) and superior } \\
\text { and external oblique } \\
\text { muscles (version B) } \\
\text { - Stretching the } \\
\text { quadratus lumborum } \\
\text { muscle }\end{array}$ & $3 \times 30 \mathrm{~s}$ & $\begin{array}{l}\text { I.P. Lying on the back with } \\
\text { raised legs bent at the knee } \\
\text { joints, arms upwards. } \\
\text { Movement: } \\
\text { 1. Raising the trunk while } \\
\text { moving the arms downwards } \\
\text { (knee joints level, hands } \\
\text { vertical). } \\
\text { 2. Holding ( } 30 \text { s). } \\
\text { 3. Lowering the legs to the } \\
\text { initial position. } \\
\text { 4. Moving the arms upwards. } \\
\text { E.P. = I.P. }\end{array}$ & $\begin{array}{l}\text { I.P. Lying on the back with } \\
\text { raised legs bent at the knee } \\
\text { joints, arms upwards. } \\
\text { Movement: } \\
\text { 1. Raising the trunk while } \\
\text { moving the arms downwards } \\
\text { (knee joints level, hands in areal } \\
\text { position). } \\
\text { Alternative 2-3 (30 s.) } \\
\text { 2. Trunk flexion to the left side. } \\
\text { 3. Trunk flexion to the left side. } \\
\text { 4. Lowering the legs to the } \\
\text { initial position while moving } \\
\text { the arms upwards. } \\
\text { E.P. = I.P. }\end{array}$ & $\begin{array}{l}\text { - During the exercise, the } \\
\text { lumbar spine should } \\
\text { globally touch the floor. } \\
\text { When a lumbar lordosis } \\
\text { accentuation can be seen, } \\
\text { the exercise should be } \\
\text { stopped. }\end{array}$ \\
\hline
\end{tabular}




\section{References}

1. Grabara, M. A comparison of the posture between young female handball players and non-training peers. J. Back Musculoskelet. Rehabil. 2014, 27, 85-92. [CrossRef]

2. Roussouly, P.; Pinheiro-Franco, J.L. Biomechanical analysis of the spino-pelvic organization and adaptation in pathology. Eur. Spine J. 2011, 20 (Suppl. S5), 609-618. [CrossRef]

3. Zwierzchowska, A.; Tuz, J. Evaluation of the impact of sagittal spinal curvatures on musculoskeletal disorders in young people. Med. Pr. 2018, 69, 29-36. [CrossRef]

4. Grabara, M. Comparison of posture among adolescent male volleyball players and non-athletes. Biol. Sport 2015, 32, 79-85. [CrossRef] [PubMed]

5. Zaina, F.; Donzelli, S.; Lusini, M.; Minnella, S.; Negrini, S. Swimming and spinal deformities: A cross-sectional study. J. Pediatr. 2015, 166, 163-167. [CrossRef] [PubMed]

6. Challoumas, D.; Artemiou, A.; Dimitrakakis, G. Dominant vs. non-dominant shoulder morphology in volleyball players and associations with shoulder pain and spike speed. J. Sports Sci. 2017, 35, 65-73. [CrossRef] [PubMed]

7. Hainline, B.; Turner, J.A.; Caneiro, J.P.; Stewart, M.; Lorimer Moseley, G. Pain in elite athletes-neurophysiological, biomechanical and psychosocial considerations: A narrative review. Br. J. Sports Med. 2017, 51, 1259-1264. [CrossRef]

8. Ortega-Santiago, R.; González-Aguado, Á.J.; Fernández-de-Las-Peñas, C.; Cleland, J.A.; de-la-Llave-Rincón, A.I.; Kobylarz, M.D.; Plaza-Manzano, G. Pressure pain hypersensitivity and referred pain from muscle trigger points in elite male wheelchair basketball players. Braz. J. Phys. Ther. 2020, 24, 333-341. [CrossRef]

9. Jeoung, B. Relationship between sitting volleyball performance and field fitness of sitting volleyball players in Korea. J. Exerc. Rehabil. 2017, 13, 647-652. [CrossRef]

10. Hendershot, B.D.; Nussbaum, M.A. Persons with lower-limb amputation have impaired trunk postural control while maintaining seated balance. Gait Posture 2013, 38, 438-442. [CrossRef] [PubMed]

11. Ahmadi, S.; Gutierrez, G.L.; Uchida, M.C. Asymmetry in glenohumeral muscle strength of sitting volleyball players: An isokinetic profile of shoulder rotations strength. J. Sports Med. Phys. Fit. 2020, 60, 395-401. [CrossRef] [PubMed]

12. Kuorinka, I.; Jonsson, B.; Kilbom, A.; Vinterberg, H.; Biering-Sørensen, F.; Andersson, G.; Jørgensen, K. Standardised Nordic questionnaires for the analysis of musculoskeletal symptoms. Appl. Ergon. 1987, 18, 233-237. [CrossRef]

13. Zwierzchowska, A.; Głowacz, M.; Batko-Szwaczka, A.; Dudzińska-Griszek, J.; Mostowik, A.; Drozd, M.; Szewieczek, J. The Body Mass Index and Waist Circumference as Predictors of Body Composition in Post CSCI Wheelchair Rugby Players (Preliminary Investigations). J. Hum. Kinet. 2014, 43, 191-198. [CrossRef]

14. Külling, F.A.; Florianz, H.; Reepschläger, B.; Gasser, J.; Jost, B.; Lajtai, G. High Prevalence of Disc Degeneration and Spondylolysis in the Lumbar Spine of Professional Beach Volleyball Players. Orthop. J. Sports Med. 2014, 2. [CrossRef]

15. Triki, M.; Koubaa, A.; Masmoudi, L.; Fellmann, N.; Tabka, Z. Prevalence and risk factors of low back pain among undergraduate students of a sports and physical education institute in Tunisia. Libyan J. Med. 2015, 10, 26802. [CrossRef]

16. Yang, C.; Lee, E.; Hwang, E.H.; Kwon, O.; Lee, J.H. Management of Sport Injuries with Korean Medicine: A Survey of Korean National Volleyball Team. Evid.-Based Complement. Altern. Med. 2016, 2016, 8639492. [CrossRef]

17. Noormohammadpour, P.; Rostami, M.; Mansournia, M.A.; Farahbakhsh, F.; Pourgharib Shahi, M.H.; Kordi, R. Low back pain status of female university students in relation to different sport activities. Eur. Spine J. 2016, 25, 1196-1203. [CrossRef]

18. Farahbakhsh, F.; Akbari-Fakhrabadi, M.; Shariat, A.; Cleland, J.A.; Farahbakhsh, F.; Seif-Barghi, T.; Mansournia, M.A.; Rostami, M.; Kordi, R. Neck pain and low back pain in relation to functional disability in different sport activities. J. Exerc. Rehabil. 2018, 14, 509-515. [CrossRef]

19. Movahed, M.; Salavati, M.; Sheikhhoseini, R.; Arab, A.M.; O'Sullivan, K. Single leg landing kinematics in volleyball athletes: A comparison between athletes with and without active extension low back pain. J. Bodyw. Mov. Ther. 2019, 23, 924-929. [CrossRef]

20. Eshraghi, A.; Safaeepour, Z.; Geil, M.D.; Andrysek, J. Walking and balance in children and adolescents with lower-limb amputation: A review of literature. Clin. Biomech. 2018, 59, 181-198. [CrossRef] [PubMed]

21. Grabara, M. Anteroposterior curvatures of the spine in adolescent athletes. J. Back Musculoskelet. Rehabil. 2014, 27, 513-519. [CrossRef]

22. Šarčević, Z.; Tepavčević, A. Association between adolescent idiopathic scoliosis and sacroiliac joint dysfunction in young athletes: A case control study. Medicine (Baltimore) 2019, 98, e15161. [CrossRef]

23. Fett, D.; Trompeter, K.; Platen, P. Prevalence of back pain in a group of elite athletes exposed to repetitive overhead activity. PLoS ONE 2019, 14, e0210429. [CrossRef] [PubMed]

24. Molik, B.; Morgulec-Adamowicz, N.; Marszałek, J.; Kosmol, A.; Rutkowska, I.; Jakubicka, A.; Kaliszewska, E.; Kozłowski, R.; Kurowska, M.; Ploch, E.; et al. Evaluation of Game Performance in Elite Male Sitting Volleyball Players. Adapt. Phys. Act. Q. 2017, 34, 104-124. [CrossRef]

25. Forthomme, B.; Wieczorek, V.; Frisch, A.; Crielaard, J.M.; Croisier, J.L. Shoulder pain among high-level volleyball players and preseason features. Med. Sci. Sports Exerc. 2013, 45, 1852-1860. [CrossRef] [PubMed]

26. Martelli, G.; Ciccarone, G.; Grazzini, G.; Signorini, M.; Urgelli, S. Isometric evaluation of rotator cuff muscles in volleyball athletes. J. Sports Med. Phys. Fit. 2013, 53, 283-288. 
27. Mizoguchi, Y.; Akasaka, K.; Otsudo, T.; Hall, T. Factors associated with low back pain in elite high school volleyball players. J. Phys. Ther. Sci. 2019, 31, 675-681. [CrossRef]

28. Paravolley Poland. Available online: Paravolleypoland.eu/historia/ (accessed on 20 August 2021). 